\title{
Kreatywny punkt widzenia w polskim filmie dokumentalnym (2000-2018)
}

\begin{abstract}
Streszczenie
Romantyczne przeciwstawienie ironii i harmonii, zaczerpnięte od Cypriana Norwida i wykorzystane przez Stanisława Barańczaka w esejach o literaturze współczesnej, jest punktem wyjścia do refleksji nad obecnością (autokreacją) autora w polskim dokumencie kreatywnym w latach 2000-2018. Artykuł odpowiada na pytania o metody poszukiwania tożsamości nowego pokolenia dokumentalistów, którzy podjęli dialog z dawnymi mistrzami, wyszli poza ramy telewizyjnego reportażu i w konsekwencji zdobyli się na trud wejścia na rynek międzynarodowy, sięgając po atrakcyjne dla niego tematy i eksperymentując $\mathrm{z}$ formą.
\end{abstract}

\section{Słowa kluczowe:}

polski film dokumentalny, film dokumentalny, kreatywny film dokumentalny, tożsamość autora w filmie dokumentalnym, historia polskiego filmu 2000-2018

\begin{abstract}
The author's aim is to present a creative point of view in the Polish documentary film 2000-2018. He is interested in documentary film theory and the place of documentary on the media market. He deals with the artistic identity of the documentary filmmaker. Kopczyński also writes about the specifics of Polish documentary film seen in a global perspective, using
\end{abstract}

${ }^{1}$ Krzysztof Kopczyński, Wydział Polonistyki, Uniwersytet Warszawski, e-mail: krzysztof. kopczynski@ntcm.com.pl, ORCID ID: https://orcid.org/0000-0002-6702-6374. 
both scientific research and his own experience as director and producer of documentary films.

\section{Keywords:}

Polish documentary film, documentary film, creative documentary, the identity of the author in a documentary film, history of Polish film 2000-2018

\section{CEL ARTYKUtU}

W artykule przedstawię uwagi nad pracą polskich twórców dokumentu kreatywnego lat 2000-2018, którzy porzucili ramy zarówno dominującego wcześniej filmu kilkunastominutowego, jak i telewizyjnego reportażu, a przy tym zdobyli się na trud wejścia na rynek międzynarodowy, sięgając po atrakcyjne dla niego tematy, niekiedy też eksperymentując z formą. Refleksja ta jest możliwa dzięki publikacji Historii polskiego filmu dokumentalnego (1945-2014) (Hendrykowska, 2015), od dawna wyczekiwanej i stanowiącej dobry wstęp do dalszych badań.

\section{KREATYWNY FILM DOKUMENTALNY}

Na wstępie trzeba wytłumaczyć, skąd w tytule artykułu znalazł się termin „kreatywny film dokumentalny”. Czy nie wystarczyłoby użyć określenia: „film dokumentalny”? Tym bardziej że - choć powszechnie stosowane i pozornie intuicyjne - sprawia ono analitykom dużo trudności. W piśmiennictwie polskim utrwaliła się definicja Mirosława Przylipiaka będąca wynikiem studiów wykorzystujących obszerne badania:

Film dokumentalny jest to taki autonomiczny, istniejący jako osobna całość przekaz audiowizualny, który prezentuje wycinek świata kompletnego, w którym znaczenia nominalne są tożsame ze źródłowymi, w którym istnieje dystans czasowy między momentem rejestracji a momentem odbioru, gdzie zostaje zachowana indeksalna wierność odtworzenia czasu i przestrzeni w ramach ujęcia, w którym realizatorzy nie ingerują w rzeczywistość przed kamerą albo ingerują i fakt tej ingerencji czynią elementem strukturalnym filmu, albo też ingerują w tym celu, aby przywrócić taki stan tej rzeczywistości, jaki istniał przed pojawieniem się ekipy filmowej, lub też aby wyzwolić prawdę 
zachowań osób filmowanych, który naśladuje w swojej strukturze konwencjonalne sposoby właściwego człowiekowi porządkowania rzeczywistości, w którym funkcja autoteliczna względem warsztatu lub tworzywa filmowego, o ile istnieje, nie może przytłumić funkcji przedmiotowej (Przylipiak, 2004, s. 50-51).

Definicja ta wymaga obecnie uzupełnień uwzględniających zmiany na rynku mediów - na przykład zwiększenie znaczenia dokumentu interaktywnego (Kopczyński, 2017a, s. 75-76). Autorzy Historii filmu dokumentalnego uważają, że „nowe kanały i sposoby komunikowania” wymuszają dodanie do propozycji Przylipiaka zdania: „Filmem dokumentalnym jest utwór filmowy, w którym na różne sposoby manifestowana jest obecność autora (poprzez uporządkowanie filmowego materiału, głos zza kadru, autor widoczny w kadrze itd.) i w którym co najmniej równorzędna wobec funkcji informacyjnej jest funkcja poetycka” (Mąka-Malatyńska, Czaja, Śliwińska, Kozłowski, 2015, s. 589-590). Wracają tym samym do pytania, w jaki sposób odróżnić filmy dokumentalne, które zaliczają się do obszaru sztuki filmowej, od faktograficznej produkcji telewizyjnej czy tworzonej na użytek portali informacyjnych. Odwołują się przy tym - za pośrednictwem Marka Hendrykowskiego (1991, s. 151) - do ustaleń Romana Jakobsona (1960, s. 431), który za przedmiot rozważań poetyki literackiej uznawał „przede wszystkim zagadnienie, co przekształca komunikat językowy w dzieło sztuki”. Warto w tym miejscu przypomnieć, że filmoznawcy nadal wykorzystują w pewnym stopniu metodologię badań literackich.

Temat kreatywności w filmie dokumentalnym podjął jako pierwszy John Grierson, łączący profesje reżysera dokumentalisty, producenta i teoretyka filmu: "Documentary, or the creative treatment of actuality, is a new art with no such background in the story and the stage as the studio product so glibly possesses" (Kerrigan, McIntyre, 2010, s. 112, Nichols, 2010, s. 6-7). Można przetłumaczyć to następująco: „Film dokumentalny, czy też twórcze (kreatywne) potraktowanie (prezentacja, przetworzenie, ujęcie) rzeczywistości, jest nową sztuką bez takiego podłoża w fabule i aktorstwie, jakie niekiedy powierzchownie przynależy produktowi powstającemu w studio”. Poglądy Griersona spotkały się z krytyką, która wprawdzie dotyczyła przede wszystkim głoszonej przez niego tezy, że film dokumentalny powinien służyć propagandzie państwowej, ale wynikała także z przeświadczenia - ugruntowanego przez cinéma-vérité, zanim okazało się ono utopią - iż dokument powinien być jak najprawdziwszym i najdokładniejszym odwzorowaniem rzeczywistości. Broniąc się przed zarzutami, Grierson precyzował, że chciał jedynie zwrócić uwagę, iż użycie żywej materii filmowej 
daje szansę wykonywania twórczej pracy, a decyzja o wyborze dokumentalnego środka przekazu jest równie poważna, jak pisarska decyzja o znalezieniu się po stronie poezji, a nie fikcji (Kerrigan, McIntyre, 2010, s. 114). Odwołał się w ten sposób do romantycznej opozycji, umieszczając film dokumentalny w obszarze poezji - a więc prawdy - ale prawdy rozumianej przecież nie jako odwzorowanie faktów. Dało to podstawę do stworzenia później kategorii „dokument poetycki”, która znalazła miejsce w refleksji teoretycznej (Nichols, 2013, s. 17-19), a przede wszystkim w historii filmu, także polskiego (Mąka-Malatyńska i in., 2015, s. 590). W polskim filmoznawstwie obecne jest również pojęcie „dokument kreacyjny”ewentualnie „dokument fabularyzowany” albo „dokument inscenizowany” - czyli wykorzystujący środki fabularne, a także wyszukane metody montażu. Określenie „kreacyjny” przypisywano przede wszystkim filmom Wojciecha Wiszniewskiego tworzącego w latach siedemdziesiątych. W jego wypadku ustalenie granicy między dokumentem i fabułą jest naprawdę trudne. Na przykładzie dorobku autora Elementarza można też zastanawiać się nad różnicą w pojmowaniu funkcji reżysera i realizatora w filmie, zwłaszcza dokumentalnym. Paradoksalnie w napisach końcowych tej krótkiej fabuły Wiszniewski jest realizatorem, a w napisach końcowych kilku dokumentów - reżyserem. Według dzisiejszych kryteriów byłby reżyserem każdorazowo, gdyż określenia „realizator” - i to nie zawsze - używa się jedynie w odniesieniu do pracy w studio i niemających statusu filmu audycji telewizyjnych lub przygotowanych na użytek internetu. Nie budzi obecnie zastrzeżeń sięganie przez dokumentalistów po metody fabularne lub animację, nawet jeśli celem jest udawanie zdjęć dokumentalnych. Jest to zgodne z cytowaną wyżej definicją Przylipiaka i przekonaniem, że film dokumentalny nie ma być „prawdziwy”ale wiarygodny. Skądinąd kryterium wiarygodności nie dotyczy jego skrajnych postaci, takich jak mockument („mock-documentary”).

Pojęcie „dokument kreatywny” wyrasta jednak nie tylko z potrzeby odróżnienia się od telewizyjnego reportażu, tv show, reality show, telewizyjnej publicystyki, notacji, a także vlogów. Dotyczy ono samego sposobu opowiadania - opartego właśnie na twórczym przetworzeniu materiału dokumentalnego i prawdziwych historii. Historie te mogą być podstawą narracji fabularnych. Już w roku 1970 Krzysztof Kieślowski napisał w pracy magisterskiej, że wystarczy przenosić je na ekran, nie trzeba niczego wymyślać (Jazdon, 2002, s. 39).

W pierwszym i drugim wydaniu popularnego podręcznika Sheili Curran Bernard Documentary Storytelling (Bernard, 2007) podtytuł brzmi: Making stronger and more dramatic nonfiction films. W wydaniu trzecim zostaje on zmieniony na Creative Nonfiction on Screen (Bernard, 2010). Ta edycja jest podstawą polskiego przekładu, który ukazał się pod tytułem Film dokumentalny. Kreatywne opowiada- 
nie (Bernard 2011). Jest to zmiana symboliczna, zwracająca uwagę na kreatywny charakter rozwoju dokumentalnych historii. Przede wszystkim właśnie rozwoju - gdyż na tę stronę powstawania filmu dokumentalnego kładzie się obecnie coraz większy nacisk, traktując ją jako proces odnoszący się do doświadczenia życiowego dokumentalisty, chwytającego rzeczy, które wyczuwa najgłębiej. O znaczeniu tego procesu piszą autorzy podręczników, przede wszystkim Michael Rabiger, który refleksji na ten temat naddaje tytuł You and the Creative Process (Rabiger, 2006, s. 15-19, 2004, s. 119-139).

Częstsze wykorzystywanie przymiotnika „kreatywny” ma też związek z uznaniem roli i swego rodzaju nobilitacją zawodu producenta. W 2001 roku ukazuje się podręcznik Myrla A. Schreibmana Creative Producing, w którym jeden z podrozdziałów zatytułowany jest The Producer as Coach (Schreibman, 2001, s. 251-253). O różnicach między producentem - odpowiedzianym wyłącznie za ekonomiczną stronę produkcji - i producentem kreatywnym opowiada - opierając się na własnym doświadczeniu - Sarah Green, której bliskie są metody wzięte z mentoringu². Coaching i mentoring dostarczają pomocnych narzędzi i oczywiście mogą być stosowane w relacji producent-twórca. Sięganie po tak profesjonalne techniki jest uzasadnione w sytuacji rosnącej konkurencji. Z obserwacji światowego rynku dokumentu ostatnich lat wynika, że kreatywnemu producentowi przypisuje się coraz większą rolę w opisanym wyżej procesie twórczym. Jest to zgodne zarówno z definicją sztuki filmowej zaproponowaną przez Davida Bordwella i Kristin Thompson (2014, s. 2-3), jak i założeniami europejskiego systemu dotowania produkcji. W 2014 roku dwa działające wcześniej fundusze europejskie - Media i Kultura - zostają połączone w „Kreatywną Europę”. W wysoko notowanej w rankingach światowych UPF Barcelona School of Management pojawiają się pierwsze w Europie studia magisterskie w dziedzinie kreatywnego dokumentu³

\section{UWARUNKOWANIA}

Film dokumentalny należy do obszaru mediów i tak jak inne media stanowi uciekający przedmiot badań - refleksja analityczna nie nadąża za zmieniającą się dynamicznie sytuacją. Ponadto jest to przedmiot niedookreślony nie tylko ze względu

\footnotetext{
2 https://www.mentorless.com/2016/07/03/creative-producer-difference-producer-sarah-green/ [dostęp: 26.11.2018].

3 https://www.barcelonaschoolofmanagement.upf.edu/en/master-in-creative-documentary [dostęp: 25.11.2018].
} 
na nieostre ramy tego rodzaju filmowego. Mimo istnienia statystyk GUS-u nie wiadomo, ile filmów dokumentalnych powstaje w Polsce rocznie. Autorzy Historii filmu dokumentalnego mówią o 200-300 tytułach (Mąka-Malatyńska i in., 2015, s. 580), brak precyzji uzasadniając specyfiką dokumentalnej produkcji telewizyjnej. A co by było, gdybyśmy uwzględnili internet? Tylko na YouTube anonimowi często twórcy wstawiają w ciągu minuty sto kilkadziesiąt godzin materiałów - przede wszystkim chyba niefikcjonalnych. Jaka część tych materiałów pochodzi z Polski? Jakiej części można by nadać status filmu dokumentalnego? Kto zdecyduje o jego przyznaniu? Nie ma na razie odpowiedzi na te pytania. Jesteśmy więc skazani na informacje i analizy cząstkowe, uprawniające jedynie do hipotez. Oglądamy przede wszystkim filmy festiwalowe, najdoskonalsze - jak się wydaje - artystycznie, dokonując jednak zawsze subiektywnego wyboru, skoro nie ma szans na poznanie reprezentatywnej części produkcji, a krytyka filmowa zajmująca się filmem dokumentalnym jest w Polsce słaba.

Przyjęta w niniejszych rozważaniach data 2000 roku ma charakter umowny. Znacznie łatwiej byłoby wytłumaczyć rok 1989 - początek nowej ery w historii krajów postkomunistycznych - albo rok 2005 - kiedy to, zgodnie z nową Ustawq o kinematografii, powstaje Polski Instytut Sztuki Filmowej, którego działalność ma zasadnicze znaczenie dla rozwoju rynku filmowego. Wydaje się jednak, że polska produkcja dokumentalna lat dziewięćdziesiątych różni się znacznie od tej z początków XXI wieku. Ta pierwsza jest albo utrzymana w konwencji krótkiego metrażu realizowanego - tak jak w poprzednich dziesięcioleciach - z myślą o emisji przed pełnometrażowymi fabułami w kinach (przykładem jest 12-minutowy dokument 89 mm od Europy Marcela Łozińskiego, nominowany do Oskara w 1994 roku), albo odpowiada na gwałtownie zmienione po roku 1989 zapotrzebowanie telewizji, przede wszystkim publicznej, stanowiącej wówczas potęgę rynkową. Po roku 2000 sytuacja się zmienia. Na polski dokument zaczyna się powoli otwierać rynek europejski. Choć Polska wchodzi do Unii Europejskiej dopiero w 2004 roku, już na przełomie wieków - przede wszystkim na podstawie umowy TVP z Europejską Telewizją Kulturalną ARTE - powstają dokumenty realizowane z myślą o widowni europejskiej. Polscy dokumentaliści biorą udział w międzynarodowych warsztatach i pitchingach (począwszy od Ex Oriente Film w Pradze w 2002 roku) i rozwijają projekty dzięki Programowi Media Unii Europejskiej. Skutki tych działań będą widoczne po kilku latach.

Rok 2000 występuje w Historii polskiego filmu dokumentalnego i jest to przekonujące nie tylko dlatego, że przełom wieków stanowi zawsze granicę. W monografii mamy spójne opracowanie lat dziewięćdziesiątych, podczas gdy opis okresu 20002014 ma charakter raczej rekonesansu, powstałego w sytuacji, gdy pożyteczny dla 
badaczy dystans czasowy nie był jeszcze możliwy4. Kończąc na roku 2018 jestem w lepszej sytuacji niż autorzy monografii, gdyż lata 2015-2018 to okres sukcesów polskiego dokumentu, stanowiących pokłosie wcześniej podejmowanych wysiłków. Mieliśmy m.in. dwie nominacje do Oskara (Joanna Anety Kopacz i Nasza klq̨twa Tomasza Śliwińskiego 2015), Europejską Nagrodę Filmową dla Komunii Anny Zameckiej (2017), trzy lata z rzędu wygrane w Locarno (15 stron świata Zuzanny Solakiewicz 2014, Bracia Wojciecha Staronia 2015, Komunia 2016), Nagrodę Specjalną Jury w konkursie pełnometrażowym IDFA - najważniejszym konkursie dokumentalnym na świecie - dla filmu Nadejdq lepsze czasy Hanny Polak (2014), zwycięstwo w konkursie krótkometrażowym na tym samym festiwalu w 2017 roku osiągnięte przez film Żalanasz Marcina Sautera, a także Grand Prix IDFA 2015 dla Don Juana Jerzego Śladkowskiego i wygraną w konkursie średniometrażowym przez Summę Andreja Kutsili w 2018 roku. Wprawdzie dwa ostatnie filmy nie były filmami sensu stricte polskimi, ale powstawały - jeśli tak można powiedzieć - w obszarze kreatywności polskiego dokumentu: pierwszy został zrealizowany przez polską ekipę, drugi dzięki polskiej koprodukcji.

W 2018 roku mamy do czynienia z dalszym rozwojem internetu jako narzędzia promocji i dystrybucji filmów, zarówno w mikro-, jak i w makroskali - czego spektakularnym dowodem jest widoczny po niespełna dwóch latach działalności sukces Netflix Polska, wyrażający się także inwestycjami w polskie produkcje, na razie fabularne. Coraz łatwiejszy jest dostęp do sprzętu i oprogramowania umożliwiającego realizację dokumentów. Na rynku dokumentalnym daleko do zwrotu inwestycji, widać za to nowe źródła finansowania publicznego. W listopadzie Sejm uchwalił Ustawę o finansowym wspieraniu produkcji audiowizualnej, komplementarną wobec Ustawy o kinematografii i zwiększającą szanse polskich producentów na rynku europejskim, którego atuty wykorzystują dotąd w stopniu nieproporcjonalnym do wielkości i znaczenia polskiej widowni (Kopczyński, 2015, s. 159-181; 2017b, s. 75-89).

Jak się wydaje, w latach 2000-2018 pojawia się też więcej niż w poprzednim dwudziestoleciu konferencji i prac badawczych na temat dokumentu. Polscy filmoznawcy i dokumentaliści uczestniczą w międzynarodowych dyskusjach branżowych. Zmienia się rozumienie sztuki dokumentu - zarówno ze względu na rosnącą konkurencję i konieczność zadbania o dotarcie do widowni, jak i nowe technologie

${ }^{4}$ Braki wynikające z tej sytuacji - np. niezauważenie w Historii filmu dokumentalnego dwóch spośród trzech polskich dokumentów nominowanych przed rokiem 2015 do Oskara: Dzieci z Leningradzkiego Hanny Polak i Andrzeja Celińskiego (2004) oraz Królika po berlińsku Bartosza Konopki (2009) - wymagają w przyszłości korekty. 
rejestracji i montażu oraz wzrastające zainteresowanie językiem filmu (warsztatem filmowym) w krytyce i filmoznawstwie, wyrażające się w publikacji opracowań dotyczących metod dokumentalnych w filmie (Rode, Pieńkowski, 2013). Mamy ciekawe eksperymenty formalne. Muzeum Powstania Warszawskiego produkuje film montażowy Powstanie warszawskie (2014), koloryzując czarno-białe archiwalia i opierając narrację na fikcyjnej historii. Dzieło odnosi sukces dystrybucyjny w kinach. Metoda ta zostaje także wykorzystana - tyle że bez fabularyzowania - w filmie Krzysztofa Talczewskiego Niepodległość (2018). Anca Damian reżyseruje animowany dokument Czarodziejska góra (2015), nagrodzony w Karlowych Warach. Andrzej Jakimowski próbuje w filmie Pewnego razu w listopadzie (2017) połączyć zdjęcia fabularne i dokumentalne, a fikcyjną historię ukazać na tle rzeczywistych wydarzeń - manifestacji z okazji Święta Niepodległości. W sposób dużo mniej doskonały tę samą metodę stosuje Antoni Krauze w Smoleńsku (2016).

Dokumentalista końca drugiej dekady XXI wieku jest zawieszony między oczekiwaną prostotą przekazu telewizyjnego i/lub YouTube'a a potrzebami widowni festiwalowych. W dużo większym stopniu niż z widzami ma do czynienia z decydentami instytucji finansujących, redaktorami zamawiającymi telewizji, dystrybutorami, selekcjonerami pitchingów i festiwali. Uczestniczy w grze marketingowej, która ma zasadnicze znaczenie dla realizacji celu, jakim jest powstanie konkretnego filmu w określonym czasie oraz przy zachowaniu przyjętych założeń budżetowych i dystrybucyjnych. Mimo że odbiorcy - nie tylko dokumentu historycznego - nadal oczekują od filmu pokazania „obiektywnej prawdy”, współczesny dokument często opowiada prawdziwe historie przy pomocy prawdziwych bohaterów, ale środkami fabularnymi. Wybitnymi przykładami takich filmów, umiejętnie łączących w narracji i rozwiązaniach warsztatowych dramat i komedię, są wspomniane wyżej Don Juan i Komunia.

\section{TOŻSAMOŚĆ DOKUMENTALISTY, TOŻSAMOŚĆ DOKUMENTALISTÓW}

Słownikjęzyka polskiego precyzuje, że tożsamość to w odniesieniu do pojedynczego człowieka „świadomość siebie, swoich cech i własnej odrębności; fakty, cechy, dane personalne pozwalające wyróżnić, rozpoznać, zidentyfikować jakąś osobę”, a w wypadku społeczności „świadomość wspólnych cech i poczucie jedności” (Dubisz, 2003, t. 4, s. 96). A zarazem:

Pojęcie tożsamości jest kategorią psychologiczno-filozoficzną określającą podmiotową świadomość bycia i bycia-w-świecie. Służy zakreśleniu indy- 
widualnych granic mentalnych w oparciu o różnicę. Świadomość odrębności opiera się na przeżywaniu przeciwstawnych sobie stanów: samotności i ograniczenia przez wspólnotę oraz na przeświadczeniu o własnej wyjątkowości. Równocześnie zapewnia poczucie bezpieczeństwa za cenę pozostania w wyznaczonych granicach: własnego ciała, mentalności, słowa i zbiorowości (Tokarz, 2006, s. 217).

W latach 2000-2018 ukazują się wywiady i teoretyczne albo wspomnieniowe teksty autorstwa dokumentalistów w ilości pozwalającej ostrożnie podjąć rozważania oparte na zdefiniowanych wyżej kategoriach. Na przełomie wieków punktem odniesienia dla filmowców stają się poglądy zmarłego w 1996 roku autora Gadających głów. Kieślowski tłumaczył swoje odejście od dokumentu dwojako. „Przez 10 lat robiłem filmy dokumentalne - mówił. - Kochałem ten gatunek i porzuciłem go z żalem i wstydem; czułem się jak człowiek, który ucieka z tonącego okręt,u zamiast ratować go lub z honorem pójść na dno. Film dokumentalny utonął. Zniknął przy ogólnym braku zainteresowania” (Dawid, 2017, s. 37). W innym miejscu natomiast przyznawał: „Nie wszystko da się opisać. To jest wielki problem filmu dokumentalnego. Łapię się sam we własną pułapkę. Im bliżej chcę być człowieka, tym bardziej człowiek się przede mną zamyka (...). Jeżeli robię film o miłości, nie mogę wejść do sypialni, jeżeli prawdziwi ludzie się tam kochają. Jeżeli robię film o śmierci, nie mogę filmować człowieka, który umiera naprawdę, bo to jest tak intymna czynność, że nie wolno mu przy tym przeszkadzać (...). Czuję się jak człowiek, który dostaje się w sfery właściwie zakazane. A to jest główny powód mojej ucieczki od filmu dokumentalnego” (Kieślowski, 1997, s. 70).

Najłatwiej jest ocenić kasandryczną opinię zawartą w pierwszej wypowiedzi, ponieważ stan faktyczny jej nie potwierdził. Film dokumentalny nie utonął - nie tonie - i nic nie wskazuje na to, by miał utonąć. Jest też obecny w kinach, inaczej wprawdzie niż krótkie metraże Kieślowskiego i innych reżyserów jego pokolenia, bo tylko w formie pełnometrażowej i dla bardzo ograniczonej widowni, ale to pole eksploatacji istnieje - a w Polsce właściwie zostało stworzone po roku 2000 - i jest wspierane przez fundusze europejskie. W dalszym ciągu gatunki dokumentalne mają wysoki udział w widowni telewizyjnej, która podlega przecież ciągłej segmentacji ze względu na wzrastającą liczbę kanałów. Oferta dokumentalna jest obecna na platformach filmowych - dokumenty pokazuje na przykład Netflix, choć w 2018 roku nie ma wśród nich jeszcze filmów polskich. Działają też - wprawdzie nie w Polsce - platformy specjalizujące się w filmie dokumentalnym. Polskie dokumenty w międzynarodowych wersjach językowych są tam czasem dostępne. 
Przejście od dokumentu do fabuły - u Kieślowskiego bardzo spektakularne dotyczy wielu polskich reżyserów. Mało kto z ważnych dokumentalistów czynnych w interesującym mnie okresie nie próbował reżyserii fabularnej. Czasem to się udawało, często kończyło porażką. W drugim wypadku niekiedy oznaczało powrót do dokumentu, kiedy indziej podejmowanie dalszych działań w obszarze fabuły. Decyzje towarzyszące temu procesowi ilustruje wywiad z nominowanym do Oskara za Królika po berlińsku Bartoszem Konopką, deklarującym, że dokumentów robić już nie będzie

z przyczyn emocjonalnych, psychologicznych. Jeśli chcę być w zgodzie ze sobą - mówi - muszę zaryzykować, przekroczyć kilka progów, otworzyć siebie (...). Przestałem wierzyć, że można dokument robić z czystej potrzeby spotkania z innym człowiekiem, oczywiście ta potrzeba też jest, ale trzeba nabrać świadomości, że pod spodem mieści się tęsknota za samym sobą.

Na pytanie, co go bardziej ogranicza, fabuła czy dokument, odpowiada:

Więcej ograniczeń jest w dokumencie, choć może to dotyczy tylko Polski, [tu postuluje się - K.K.] wierność rzeczywistości (...), nie chodzi o to, żebyś opowiadał o sobie, tylko o to, żeby ciebie w tym filmie w ogóle nie było widać (...). Początkowo mi to pasowało, tylko że wtedy kompletnie porzuciłem siebie jako człowieka, rozpuszczałem się w tym, co na zewnątrz. Kompletnie nie byłem dogadany ze sobą, nie wiedziałem, kim jestem; kolejne rzeczy, które robiłem w życiu, były kolejnymi aktami porzucania siebie, swoich pragnień i oczekiwań. Tak się w tym zatraciłem, że ten dokument był wybawieniem (Socha, 2014a, s. 59, 63).

Zarysowany w wypowiedziach Kieślowskiego i Konopki problem poszukiwania tożsamości autorskiej poprzez przyjęcie drogi twórczej, na której - dla nich - reżyseria filmów dokumentalnych jest porzucanym w pewnym momencie etapem dochodzenia do poznawania samego siebie przez ustalenie charakteru relacji z rzeczywistością, można zapisać w formie listy zagadnień odnoszących się do dwóch obszarów: tożsamości twórcy i jego obecności na rynku. W pierwszej grupie znajdą się następujące kwestie:

- ja wobec samego siebie i najbliższego otoczenia;

- walka o poczucie własnej wartości - z fabularzystami, z reżyserami gatunków komercyjnych - moje ego, ucieczka w stronę fabuły lub komercji; 
- ja wobec bohaterów moich filmów; postacie historyczne, mędrcy, artyści, członkowie mojej rodziny i zwykli ludzie jako bohaterowie moich filmów;

- zakres mojej obecności w filmie;

- ja wobec poprzedników - dialog z dawnymi mistrzami;

- ja wobec Polski i świata; moja wizja polskości;

- ja wobec Boga i religii;

- mój pogląd na temat etyki, epistemologii i transgresji oraz roli dokumentu w tych sferach; moja gotowość do przekraczania granic.

Druga grupa obejmuje:

- rynkowe ograniczenia dokumentu - również ekonomiczne; związany z tym wybór gatunku;

- ja na rynku mediów - wobec niefilmowych gatunków niefikcjonalnych i wobec oczekiwań decydentów, również dotyczących wyboru tematu filmu;

- ja wobec odbiorcy i jego wyobrażonych potrzeb;

- działania marketingowe producenta i reżysera;

- zewnętrzne kryteria oceny pracy: branżowe, eksperckie, festiwalowe, będące domeną krytyki filmowej i dziennikarstwa, komercyjne.

Warto zwrócić uwagę, że możliwe pola wyboru są w Polsce - czasem podobnie jak w innych krajach - zawężone. Nie mają u nas znaczenia - przy całym szacunku dla podejmowanych wysiłków - dokument naukowy i przyrodniczy. Niepodległość Talczewskiego potwierdza, iż montażowy film historyczny - wymagający dużego budżetu, z powodzeniem uprzednio realizowany przez Macieja Drygasa (Jeden dzień w PRL, 2005, Cudze listy, 2010) - w dalszym ciągu spełnia wysokie kryteria artystyczne. W 2018 roku jednak - inaczej niż w latach poprzednich - decyzja o podjęciu tematu z historii najnowszej wiązała się z określeniem stosunku do obowiązującej polityki historycznej, której zwolennicy zajmują duży segment rynku (Kornacki, 2016; Jazdon, 2005). Problem ten dotyczy także w pewnym stopniu dokumentu społecznego, politycznego i rzadko występującego w Polsce dokumentu śledczego. Nie należy również lekceważyć faktu, że próba zachowania niezależności w politycznym i środowiskowym sensie wiąże się z koniecznością znalezienia innych źródeł utrzymania - chyba że jest on jednocześnie reżyserem, operatorem, montażystą i producentem, najlepiej działającym na rynku międzynarodowym. Trudno też dokumentaliście liczyć na skuteczne wsparcie instytucjonalne i środowiskowe, choć co pewien czas podejmowane są działania w tym kierunku - takie jak utworzenie w maju 2017 roku Gildii Polskich Reżyserów Dokumentalnych (Kopczyński 2015, s. 178-179; 2017b, s. 89). 
W literaturze przedmiotu wskazuje się na istnienie w dokumencie społecznym „szkoły Fidyka” i „szkoły Marcela Łozińskiego” - które miałyby różnić się przede wszystkim stosunkiem do bohaterów, szczególnie wytyczeniem granicy etycznej w ujawnianiu niekorzystnych dla nich sytuacji. Najpełniej - odwołując się do Tadeusza Lubelskiego i wskazując na związki Łozińskiego z Karabaszem - analizuje ten schemat Katarzyna Mąka-Malatyńska (2006). Najważniejszym jak dotąd przykładem „przekraczania dopuszczalnych granic” pozostaje traktowany jako sztandarowy dokument „szkoły Fidyka” film Marcina Koszałki Takiego pięknego syna urodziłam (1999), nagrodzony przez jury studenckie na Krakowskim Festiwalu Filmowym za „uzasadniony ekshibicjonizm”, wywołujący skrajne emocje i obrosły wieloma interpretacjami (Wiśniewska, 2011, Wojciechowska, 2013, Kozubek, 2016). Jak wskazuje jednak trafnie sam reżyser, odwołując się m.in. do ostrych słów Marcela Łozińskiego i Kazimierza Karabasza na swój temat, realizacja przez Łozińskich dyptyku Ojciec i syn oraz Ojciec i syn w podróży (2013) zamyka właściwie dyskusję, gdyż w filmach tych ujawnione zostają drastyczne szczegóły z życia bohaterów, a ich premierze towarzyszy ostry konflikt między nimi (Socha, 2014b, s. 74-76). Inne przejawy „uzasadnionego ekshibicjonizmu” - na przykład Miłość bezwarunkowa Rafała Łysaka (2018) - nie budzą już takich emocji, być może dlatego, że są nakręcone z dużym poczuciem humoru, tak potrzebnym polskim widzom. Te filmy i zjawiska to przejawy autobiografizmu, którego znaczenie w dokumencie w omawianym okresie rośnie (Lubelski, 2016, s. 48; Podsiadło, 2013). Jest to zgodne z tendencją światową - na co dowodem może być Grand Prix IDFA 2017 dla filmu Inna strona wszystkiego Mili Turajlic.

\section{OBSZARY KREATYWNOŚCI}

Konwergencja mediów, rosnąca rola internetu, konieczność znalezienia nowych źródeł finansowania i ciągły niedostatek wiedzy o oczekiwaniach odbiorców skłaniają do kreatywnych działań w tym kierunku. Chodzi już nie tylko o wiedzę, ale o rozwój widowni polegający na budowaniu trwałych relacji między twórcami i widzami. Zamierzenia takie są wspierane przez Kreatywną Europę, a najważniejszą rolę odegrają w nich instytucje kultury, festiwale tworzące obecnie jedyną atrakcyjną dla dokumentalisty hierarchię ocen a także szkoły, uczelnie i inne organizacje zajmujące się edukacją (np. Filmoteka Szkolna i Nowe Horyzonty Edukacji Filmowej). I choć szerokie projekty edukacyjne związane z filmem także dokumentalnym - wyglądają dziś utopijnie, warto odnotować, że istnieją (Bobiński, 2016; Jaskulski, Koryciński, 2016; Socha, Taras, 2014, s. 7-8). 
Rozwój widowni ma związek z tworzeniem alternatywnych źródeł finansowania - takich jak crowdfunding - i zapewnieniem skutecznego dostępu do międzynarodowego rynku (wśród nowych inicjatyw w tym obszarze wyróżnia się polska platforma www.pitchthedoc.com). Niefestiwalowa dystrybucja polskich dokumentów za granicą nie polepsza się, a konkurencja rośnie (Kopczyński, 2015).

Oczywistym obszarem kreatywności jest poszukiwanie adekwatnej dla wybranego tematu formy, a także samo znajdowanie tematów. Lata 2000-2018 dowodzą, że cenne są wszelkie eksperymenty. Jak się wydaje, dokumentalistom pomogłoby też, gdyby w większym stopniu byli traktowani jako uczestnicy życia intelektualnego, a to wymaga akademickiej hermeneutyki filmów i wzmocnienia krytyki filmowej.

Nie ma sporu, że kino jest „pewną społeczną praktyką komunikacyjną, przestrzenią, w której demokratyczna wspólnota może dyskutować o kluczowych dla siebie problemach” (Majmurek, Wiśniewska, 2011, s. 6). To obszar, którego znaczenie rośnie w czasach politycznych kryzysów. Mało atrakcyjny dla artystów, bliski publicystyce, niebędący zwykle przedmiotem głębokich studiów. Nie można go jednak lekceważyć, gdyż - jak dowodzą ostatnio dyskusje wokół Dobrej zmiany Konrada Szołajskiego (2018) - istnieje społeczne przekonanie o dokumentacyjnym znaczeniu filmu dokumentalnego i oczekiwanie, że odegra on ważną rolę w kreowaniu politycznych postaw. Takim filmem była niewątpliwie dla Serbów wspomniana wyżej Inna strona wszystkiego. Film tej rangi nie powstał w ostatnich latach w Polsce, choć w pierwszym dziesięcioleciu XXI wieku można by doszukiwać się podobnych ambicji w twórczości Marii Zmarz-Koczanowicz (Noc z generałem, 2001, Pokolenie 89, Dzieci rewolucji, 2002, Kocham Polskę, 2007).

W 1973 roku Stanisław Barańczak wydał Ironię i harmonię - tom szkiców o literaturze, tytułem nawiązujący do dwóch wierszy Norwida ze zbioru Vade-mecum. Barańczak proponuje podział sztuki współczesnej na pasywną, akceptującą i aktywną - służącą przebudzeniu. W drugim wypadku najważniejszym narzędziem, po które może sięgnąć twórca, staje się ironia, rozumiana „nie jako wygodny dystans, ale jako umiejętność czynnego włączenia się w konflikty świata i ludzkiej świadomości oraz odnalezienia ich pozytywnej syntezy” (Barańczak, 1973, s. 8). Wydaje mi się, że zarysowana w ten sposób opozycja będzie miała w najbliższym czasie kapitalne znaczenie dla prób odnalezienia tożsamości przez dokumentalistów i ich kreatywnej relacji z rzeczywistością - bez względu na to, czy będą robić filmy w Polsce, czy za granicą. Norwidowskie przesłanie - że nakazem dla twórcy jest zrozumienie dziejów, które jest niemożliwe bez ironii jest bowiem, czasem boleśnie, ponadczasowe. 


\section{Bibliografia}

Adamczak, M., Klejsa, K. (red.). (2015). Wokół zagadnień dystrybucji filmowej. Łódź: Wydawnictwo Biblioteki Państwowej Wyższej Szkoły Filmowej, Telewizyjnej i Teatralnej.

Barańczak, S. (1973). Ironia i harmonia. Szkice o najnowszej literaturze polskiej. Warszawa: Czytelnik.

Bernard, S.C. (2007). Documentary Storytelling. Making Stronger and More Dramatic Nonfiction Films (2nd edition). Oxford: Elsevier, Focal Press.

Bernard, S.C. (2010). Documentary Storytelling. Creative Nonfiction on Screen (3rd edition). Oxon: Focal Press.

Bernard, S.C. (2011). Film dokumentalny. Kreatywne opowiadanie. Warszawa: Wydawnictwo Wojciech Marzec.

Bławut, J. (2010). Bohater w filmie dokumentalnym. Łódź: Wydawnictwo Państwowej Wyższej Szkoły Filmowej, Telewizyjnej i Teatralnej.

Bobiński, W. (2016). Wykształcić widza. Sztuka oglqdania w edukacji polonistycznej. Kraków: Towarzystwo Autorów i Wydawców Prac Naukowych UNIVERSITAS.

Bordwell, D., Thompson, K. (2014). Film Art. Sztuka filmowa. Wprowadzenie. Warszawa: Wydawnictwo Wojciech Marzec.

Dawid, L. (2017). Dokument umarł? Kamera cyfrowa jako narzędzie dokumentalisty. W: K. Mąka-Malatyńska (red.), Od obserwacji do animacji. Autorzy o kinie dokumentalnym (s. 37-47). Łódź: Wydawnictwo Biblioteki Państwowej Wyższej Szkoły Filmowej, Telewizyjnej i Teatralnej.

Dubisz, S. (red.). (2003). Uniwersalny słownik języka polskiego. Warszawa: Wydawnictwo Naukowe PWN.

Hendrykowska, M. (red.). (2005). Klucze do rzeczywistości. Szkice i rozmowy o polskim filmie dokumentalnym po roku 1989. Poznań: Wydawnictwo Naukowe UAM.

Hendrykowska, M. (red.). (2015). Historia polskiego filmu dokumentalnego (1945-2014). Poznań: Wydawnictwo Naukowe UAM.

Hendrykowski, M. (1991). Autor w filmie dokumentalnym. W: M. Hendrykowski (red.), Autor w filmie. Z dziejów ewolucji filmowych form artystycznych (s. 146-156). Poznań: Państwowa Wyższa Szkoła Sztuk Plastycznych i Uniwersytet Adama Mickiewicza.

Hendrykowski, M. (red.). (1991). Autor w filmie. Z dziejów ewolucji filmowych form artystycznych. Poznań: Państwowa Wyższa Szkoła Sztuk Plastycznych i Uniwersytet Adama Mickiewicza.

Jagielski, S., Podsiadło, M. (red.). (2017) Kino polskie jako kino transnarodowe. Kraków: Towarzystwo Autorów i Wydawców Prac Naukowych UNIVERSITAS.

Jakobson, R. (1960). Poetyka w świetle językoznawstwa. Pamiętnik Literacki 51 (2), s. 431-473.

Jaskulski, P., Koryciński, M. (red.). (2016). Różne oblicza edukacji audiowizualnej. Edukacja filmowa w Polsce i świecie. Rozwiqzania systemowe i studia przypadków. Warszawa: COME UW, Eureka Media. Pobrane z: https://come.uw.edu.pl/peam/u/ PEAM-Rozne_oblicza_edukacji_audiowizualnej.pdf.

Jazdon, M. (2002). Dokumenty Kieślowskiego. Poznań: Wydawnictwo Poznańskie. Jazdon, M. (2005). Historia w polskim filmie dokumentalnym przełomu wieków. W: M. Hendrykowska (red.), Klucze do rzeczywistości. Szkice i rozmowy o polskim filmie dokumentalnym po roku 1989 (s. 47-65). Poznań: Wydawnictwo Naukowe UAM. 
Jazdon, M., Mąka-Malatyńska, K. (red.). (2011). Zobaczyć siebie. Polski film dokumentalny przełomu wieków. Poznań: Centrum Kultury Zamek.

Karabasz, K. (2009). Odczytać czas. Łódź: Wydawnictwo Państwowej Wyższej Szkoły Filmowej, Telewizyjnej i Teatralnej.

Kerrigan, S., McIntyre, P. (2010). The ‘creative treatment of actuality’: Rationalizing and reconceptualizing the notion of creativity for documentary practice. Journal of Media Practice, 11 (2), s. 111-130.

Kieślowski, K. (1997). O sobie. Kraków: Wydawnictwo Znak.

Kita, B. (red.). (2006). Przestrzenie tożsamości we współczesnym kinie europejskim. Kraków: Wydawnictwo RABID.

Kopczyński, K. (2015). Dystrybucja polskich filmów dokumentalnych w świecie - smuga cienia. W: M. Adamczak, K. Klejsa, (red.), Wokół zagadnień dystrybucji filmowej (s. 159-181). Łódź: Wydawnictwo Biblioteki Państwowej Wyższej Szkoły Filmowej, Telewizyjnej i Teatralnej.

Kopczyński, K. (2017a). Interaktywny film dokumentalny - historia i perspektywy rozwoju. Media - Kultura - Komunikacja Społeczna, 13 (2), s. 69-83.

Kopczyński, K. (2017b). Koprodukcja międzynarodowa polskich filmów dokumentalnych w latach 2005-2015 (rekonesans). W: S. Jagielski, M. Podsiadło (red.), Kino polskie jako kino transnarodowe (s. 75-89). Kraków: Towarzystwo Autorów i Wydawców Prac Naukowych UNIVERSITAS.

Kornacki, K. (2016). Film Open Group. Errata do historii. W: T. Szczepański, M. Kozubek (red.), Polski film dokumentalny w XXI wieku (s. 91-108). Łódź: Państwowa Wyższa Szkoła Filmowa, Telewizyjna i Teatralna im. Leona Schillera w Łodzi, Wydawnictwo Uniwersytetu Łódzkiego.

Kozubek, M. (2016). (Auto)terapeutyczny wymiar filmów Marcina Koszałki. W: T. Szczepański, M. Kozubek (red.), Polski film dokumentalny w XXI wieku (s. 63-76). Łódź: Państwowa Wyższa Szkoła Filmowa, Telewizyjna i Teatralna im. Leona Schillera w Łodzi, Wydawnictwo Uniwersytetu Łódzkiego.

Lubelski, T. (2016). Autobiograficzna triada w polskim filmie dokumentalnym czasów najnowszych. W: T. Szczepański, M. Kozubek (red.), Polski film dokumentalny w XXI wieku (s. 29-61). Łódź: Państwowa Wyższa Szkoła Filmowa, Telewizyjna i Teatralna im. Leona Schillera w Łodzi, Wydawnictwo Uniwersytetu Łódzkiego.

Majmurek, J., Wiśniewska, A. (2011). Wstęp. Dokumenty polityki. W: A. Wiśniewska (red.), Polskie kino dokumentalne 1989-2009. Historia polityczna (s. 5-8). Warszawa: Wydawnictwo Krytyki Politycznej.

Mąka-Malatyńska, K. (2005). Trzy szkoły opowiadania o świecie i człowieku. W: M. Hendrykowska (red.), Klucze do rzeczywistości. Szkice i rozmowy o polskim filmie dokumentalnym po roku 1989 (s. 27-46). Poznań: Wydawnictwo Naukowe UAM.

Mąka-Malatyńska, K. (red.) (2017). Od obserwacji do animacji. Autorzy o kinie dokumentalnym. Łódź: Wydawnictwo Biblioteki Państwowej Wyższej Szkoły Filmowej, Telewizyjnej i Teatralnej.

Mąka-Malatyńska, K., Czaja, J., Śliwińska, A., Kozłowski, K. (2015). Polski film dokumentalny po roku 2000. W: M. Hendrykowska (red.), Historia polskiego filmu dokumentalnego (1945-2014) (s. 573-725). Poznań: Wydawnictwo Naukowe UAM. 
Nichols, B. (2010). Introduction to Documentary. Bloomington-Indianapolis: Indiana University Press.

Nichols, B. (2013). Typy filmu dokumentalnego. W: D. Rode, M. Pieńkowski (red.), Metody dokumentalne w filmie (s. 13-44). Łódź: Wydawnictwo Biblioteki Państwowej Wyższej Szkoły Filmowej, Telewizyjnej i Teatralnej.

Podsiadło, M. (2013). Autobiografizm filmowy jako ślad podmiotowej egzystencji. Kraków: Towarzystwo Autorów i Wydawców Prac Naukowych UNIVERSITAS.

Przylipiak, M. (2004). Poetyka kina dokumentalnego, Gdańsk-Słupsk: Wydawnictwo Uniwersytetu Gdańskiego, Wydawnictwo Pomorskiej Akademii Pedagogicznej w Słupsku.

Rabiger, M. (2004). Directing the Documentary. Oxford: Elsevier, Focal Press.

Rabiger, M. (2006). Developing Story Ideas. Oxford: Elsevier, Focal Press.

Renov, M. (red.). (1993). Theorizing Documentary. New York-London: Routledge. Taylor \& Francis Group.

Renov, M. (1993). Introduction: The Truth About Non-Fiction, Toward a Poetics of Documentary. W: M. Renov (red.),Theorizing Documentary (s. 1-36). New York-London: Routledge. Taylor \& Francis Group.

Rode, D., Pieńkowski, M. (red.). (2013). Metody dokumentalne w filmie. Łódź: Wydawnictwo Biblioteki Państwowej Wyższej Szkoły Filmowej, Telewizyjnej i Teatralnej.

Schreibman, M.A. (2001). The Indie Producer's Handbook. Creative Producing from A to Z. Los Angeles: Lone Eagle Publishing Company, LLC.

Socha, J. (2014a). Chcę opowiadać o sobie. Z Bartoszem Konopką rozmawia Jakub Socha. W:

J. Socha, K. Taras, DOCq̨d. Rozmowy z polskimi dokumentalistami (s. 47-67). Katowice: Wydawnictwo Filmoteki Śląskiej.

Socha, J. (2014b). Mam dość udawania. Z Marcinem Koszałką rozmawia Jakub Socha. W: J. Socha, K. Taras, DOCq̨d. Rozmowy z polskimi dokumentalistami (s. 71-93). Katowice: Wydawnictwo Filmoteki Śląskiej.

Socha, J., Taras, K. (2014). DOCq̨d. Rozmowy z polskimi dokumentalistami. Katowice: Wydawnictwo Filmoteki Śląskiej.

Szczepański, T., Kozubek, M. (red.). (2016). Polski film dokumentalny w XXI wieku. Łódź: Państwowa Wyższa Szkoła Filmowa, Telewizyjna i Teatralna im. Leona Schillera w Łodzi, Wydawnictwo Uniwersytetu Łódzkiego.

Tokarz, B. (2006). Fabuła jako konstrukt tożsamości. W: B. Kita (red.), Przestrzenie tożsamości we współczesnym kinie europejskim (s. 217-230). Kraków: Wydawnictwo RABID.

Wiśniewska, A. (2011). Takiego pięknego syna urodziłam Marcina Koszałki, czyli zaprzepaszczony potencjał krytyczny dokumentu autobiograficznego. W: A. Wiśniewska (red.), Polskie kino dokumentalne 1989-2009. Historia polityczna (s. 59-68). Warszawa: Wydawnictwo Krytyki Politycznej.

Wiśniewska, A. (red.) (2011). Polskie kino dokumentalne 1989-2009. Historia polityczna. Warszawa: Wydawnictwo Krytyki Politycznej.

Wojciechowska, M. (2013). Kino dokumentalne jako forma terapii - twórczość Marcina Koszałki. W: W: D. Rode, M. Pieńkowski (red.), Metody dokumentalne w filmie (s. 341-358). Łódź: Wydawnictwo Biblioteki Państwowej Wyższej Szkoły Filmowej, Telewizyjnej i Teatralnej. 